J. Appl. Glycosci., 51, 241-246 (2004)

(C) 2004 The Japanese Society of Applied Glycoscience

Note

\title{
Properties of Starches from Potato Varieties Grown in Hokkaido
}

\author{
(Received March 18, 2004 ; Accepted May 12, 2004) \\ Takahiro Noda, ${ }^{1, *}$ Shogo Tsuda, ${ }^{1}$ Motoyuki Mori, ${ }^{1}$ Shigenobu Takigawa, \\ Chie Matsuura-Endo, ${ }^{1}$ Naoto Hashimoto ${ }^{2}$ and Hiroaki Yamauchi ${ }^{1}$ \\ ${ }^{1}$ Department of Upland Agriculture, National Agricultural Research Center for Hokkaido Region \\ (Shinsei, Memuro, Hokkaido 082-0071, Japan) \\ ${ }^{2}$ Division of Applied Bioscience, Graduate School of Agriculture, Hokkaido University \\ (Kita-9 Nishi-9, Kita-ku, Sapporo 060-8589, Japan)
}

\begin{abstract}
Using potato cultivars grown in Hokkaido, the starch properties in potato tubers were characterized. The starch properties determined in this study were the contents of amylose and phosphorus, granule size distribution, and pasting properties using a rapid visco-analyzer. There were wide variations in starch parameters among the 96 potato starch samples used. A high phosphorus content of starch was closely associated with high peak viscosity and breakdown and low peak viscosity temperature. Although the amylose content also had an effect on pasting properties, the correlation coefficients between the phosphorus content and pasting properties were higher than those between the amylose content and pasting properties.
\end{abstract}

Key words: potato starch, phosphorus content, pasting properties

The potato is an important starch crop with major production and consumption in many parts of the world. Potato starch is produced in factories in Hokkaido, the northernmost island of Japan. The major cultivars used in the starch industry in Hokkaido are Benimaru and Konafubuki. ${ }^{1)}$ In addition, potato cultivars that are primarily used for market sales and food processing are also used for starch production. Irish Cobbler and May Queen are typical cultivars used for market sales, while Toyoshiro and Hokkaikogane are used for food processing. ${ }^{1)}$

Among the commercial starches, potato starch has the highest pasting viscosity. The characteristic is largely attributed to starch-bound phosphate. Potato starch has a higher concentration of phosphate than the starches from other botanical sources. ${ }^{2)}$ The phosphorus content of potato starch usually ranges from 600 to $1000 \mathrm{ppm}$. Thus, as potato starch has unique textural characteristics, it is preferentially used in fish paste products and as an ingredient of various noodles.

In many crops including potato, the starch properties change according to the cultivars and environmental factors. Since the 1970s, some researchers have studied the varietal differences in starch properties using various types of Japanese potatoes. ${ }^{3-6)}$ Our previous study revealed that the harvest date had an impact on the starch properties in six different potato cultivars grown in Hokkaido." However, there is incomplete information on the effects of the cultivars and growth conditions on starch properties using many recently released samples of potato cultivars grown in Hokkaido.

The objective of this study was to investigate and compare the starch properties, such as the contents of amylose and phosphorus, granule size distribution, and pasting properties using a rapid visco-analyzer, of representative

${ }^{*}$ Corresponding author. (Tel. +81-155-62-9278, Fax. +81-15562-2926, E-mail: noda@affrc.go.jp). potato cultivars grown in Hokkaido. Furthermore, we evaluated the range of the starch properties within many samples of potatoes and studied the contribution of componential characteristics and granule size to pasting properties in order to provide valuable information for researchers who study starch behavior and utilization.

A total of 96 potato samples from 40 cultivars used in this study are listed in Table 1. Eighty-seven potato samples differing in plant and harvest dates were produced in 2001 and 2002 at the experimental farm at the National Agricultural Research Center for the Hokkaido Region at Memuro, Hokkaido. Starches were isolated from these 87 potato samples as described previously. ${ }^{7)}$ Nine starch samples produced by Jinno Starch Co., Sarabetsu, Hokkaido, were purchased and also used for this experiment. Out of nine, five were derived from Konafubuki, Benimaru, Eniwa, Hokkaikogane, and Norin No. 1 produced in 2002 on a farm near Jinno Starch Co., and four were derived from Benimaru, Eniwa, Hokkaikogane, and Waseshiro produced in 2003 on a farm near Jinno Starch Co.

Starch properties, namely the contents of amylose and phosphorus, granule size distribution, and RVA paste viscosity of starches were determined as described previously. ${ }^{7)}$ The determinations of the amylose content were made in triplicate. The analyses of the granule size distribution and RVA paste viscosity were carried out in duplicate. The estimations of phosphorus content were performed only once or in duplicate. The correlation coefficients among starch properties were also calculated. Calculations were performed using Microsoft Excel 5.0 for Windows.

First, we investigated and compared the starch properties among the 15 major Japanese potato cultivars and one promising candidate for a cultivar. Konafubuki and Benimaru are typical cultivars used for starch production; Eniwa, Sakurafubuki, Astarte, and Early Starch are also commonly used. Hokkai No. 87 is a promising candidate 
Table 1. Potato samples used in this study.

\begin{tabular}{|c|c|c|c|c|}
\hline Cultivar & Place** & Year & Plant date & Harvest date \\
\hline Konafubuki* & $\mathrm{M}$ & 2001 & 9 May & 29 Aug. \\
\hline Konafubuki* & M & 2001 & 9 May & 27 Sept. \\
\hline Konafubuki & $\mathrm{M}$ & 2001 & 9 May & 1 Oct. \\
\hline Konafubuki & $\mathrm{M}$ & 2002 & 24 Apr. & 30 Sept. \\
\hline Konafubuki & M & 2002 & 7 May & 3 Oct. \\
\hline Konafubuki & $\mathrm{J}$ & 2002 & Unknown & Unknown \\
\hline Benimaru* & M & 2001 & 9 May & 29 Aug. \\
\hline Benimaru* & M & 2001 & 9 May & 27 Sept. \\
\hline Benimaru & M & 2001 & 8 May & 1 Oct. \\
\hline Benimaru & $\mathrm{M}$ & 2002 & 24 Apr. & 30 Sept. \\
\hline Benimaru & $\mathrm{J}$ & 2002 & Unknown & Unknown \\
\hline Benimaru & $\mathrm{J}$ & 2003 & Unknown & Unknown \\
\hline Eniwa & M & 2001 & 9 May & 27 Sept. \\
\hline Eniwa & M & 2002 & 24 Apr. & 30 Sept. \\
\hline Eniwa & M & 2002 & 7 May & 3 Oct. \\
\hline Eniwa & $\mathrm{J}$ & 2002 & Unknown & Unknown \\
\hline Eniwa & $\mathrm{J}$ & 2003 & Unknown & Unknown \\
\hline Sakurafubuki* & M & 2001 & 9 May & 29 Aug. \\
\hline Sakurafubuki* & $\mathrm{M}$ & 2001 & 9 May & 27 Sept. \\
\hline Sakurafubuki & $\mathrm{M}$ & 2002 & 24 Apr. & 30 Sept. \\
\hline Astarte* & $\mathrm{M}$ & 2001 & 9 May & 29 Aug. \\
\hline Astarte & M & 2001 & 8 May & 20 Sept. \\
\hline Astarte* & M & 2001 & 9 May & 27 Sept. \\
\hline Early Starch* & M & 2001 & 9 May & 29 Aug. \\
\hline Early Starch* & M & 2001 & 9 May & 27 Sept. \\
\hline Early Starch & M & 2002 & 7 May & 3 Oct. \\
\hline Early Starch & M & 2002 & 24 Apr. & 30 Sept. \\
\hline Hokkai No. $87^{*}$ & M & 2001 & 9 May & 29 Aug. \\
\hline Hokkai No. $87^{*}$ & M & 2001 & 9 May & 27 Sept. \\
\hline Hokkai No. 87 & M & 2001 & 8 May & 1 Oct. \\
\hline Hokkai No. 87 & M & 2002 & 24 Apr. & 30 Sept. \\
\hline Irish Cobbler & $\mathrm{M}$ & 2001 & 9 May & 24 Aug. \\
\hline Irish Cobbler & M & 2001 & 9 May & 27 Sept. \\
\hline Irish Cobbler & $\mathrm{M}$ & 2001 & 24 Apr. & 14 Sept. \\
\hline Irish Cobbler & M & 2002 & 7 May & 3 Oct. \\
\hline Irish Cobbler & M & 2002 & 24 Apr. & 30 Sept. \\
\hline May Queen & M & 2001 & 9 May & 27 Sept. \\
\hline May Queen & M & 2001 & 24 Apr. & 14 Sept. \\
\hline May Queen & M & 2002 & 7 May & 3 Oct. \\
\hline Kita-akari & M & 2001 & 8 May & 18 Sept. \\
\hline Kita-akari & M & 2001 & 9 May & 27 Sept. \\
\hline Kita-akari & M & 2002 & 7 May & 24 Sept. \\
\hline Touya & M & 2001 & 9 May & 27 Sept. \\
\hline Touya & M & 2002 & 24 Apr. & 30 Sept. \\
\hline Touya & M & 2002 & 7 May & 3 Oct. \\
\hline Toyoshiro & M & 2001 & 9 May & 24 Aug. \\
\hline Toyoshiro & M & 2001 & 9 May & 27 Sept. \\
\hline Toyoshiro & M & 2001 & 24 Apr. & 14 Sept. \\
\hline
\end{tabular}

\begin{tabular}{|c|c|c|c|c|}
\hline Cultivar & Place** & Year & Plant date & Harvest date \\
\hline Toyoshiro & $\mathrm{M}$ & 2002 & 7 May & 3 Oct. \\
\hline Toyoshiro & M & 2002 & 24 Apr. & 30 Sept. \\
\hline Hokkaikogane & M & 2001 & 9 May & 27 Sept. \\
\hline Hokkaikogane & M & 2001 & 8 May & 1 Oct. \\
\hline Hokkaikogane & M & 2002 & 7 May & 3 Oct. \\
\hline Hokkaikogane & M & 2002 & 24 Apr. & 30 Sept. \\
\hline Hokkaikogane & $\mathrm{J}$ & 2002 & Unknown & Unknown \\
\hline Hokkaikogane & $\mathrm{J}$ & 2003 & Unknown & Unknown \\
\hline Waseshiro & M & 2001 & 8 May & 18 Sept. \\
\hline Waseshiro & $\mathrm{M}$ & 2001 & 9 May & 27 Sept. \\
\hline Waseshiro & M & 2002 & 7 May & 3 Oct. \\
\hline Waseshiro & $\mathrm{J}$ & 2003 & Unknown & Unknown \\
\hline Norin No. 1 & M & 2001 & 9 May & 27 Sept. \\
\hline Norin No. 1 & M & 2002 & 7 May & 3 Oct. \\
\hline Norin No. 1 & $\mathrm{~J}$ & 2002 & Unknown & Unknown \\
\hline Sayaka & M & 2001 & 9 May & 27 Aug. \\
\hline Sayaka & M & 2001 & 9 May & 27 Sept. \\
\hline Sayaka & M & 2002 & 7 May & 3 Oct. \\
\hline Green Mountain & M & 2001 & 9 May & 27 Sept. \\
\hline Green Mountain & M & 2002 & 2 May & 25 Sept. \\
\hline Cherokee & M & 2001 & 9 May & 27 Sept. \\
\hline Cherokee & M & 2002 & 2 May & 25 Sept. \\
\hline Kennebec & M & 2001 & 9 May & 27 Sept. \\
\hline Kennebec & M & 2002 & 2 May & 25 Sept. \\
\hline Rishiri & M & 2001 & 9 May & 27 Sept. \\
\hline Rishiri & M & 2002 & 2 May & 25 Sept. \\
\hline Inca-no-mezame & M & 2001 & 25 Apr. & 14 Sept. \\
\hline Inca-no-mezame & M & 2002 & 7 May & 13 Sept. \\
\hline Beni-akari & M & 2001 & 9 May & 27 Sept. \\
\hline Beni-akari & M & 2002 & 7 May & 3 Oct. \\
\hline Early rose & M & 2001 & 9 May & 27 Sept. \\
\hline Vermont Gold Coin & M & 2001 & 9 May & 27 Sept. \\
\hline Kintoki-imo & M & 2001 & 9 May & 27 Sept. \\
\hline Pepo & M & 2001 & 9 May & 27 Sept. \\
\hline Hokkai-aka & M & 2001 & 9 May & 27 Sept. \\
\hline Yukijiro & M & 2001 & 9 May & 27 Sept. \\
\hline Dejima & M & 2001 & 9 May & 27 Sept. \\
\hline Tarumae & M & 2001 & 9 May & 27 Sept. \\
\hline Tunika & M & 2001 & 9 May & 27 Sept. \\
\hline Nishiyutaka & M & 2001 & 9 May & 27 Sept. \\
\hline Toyoakari & M & 2001 & 9 May & 27 Sept. \\
\hline Musamaru & M & 2001 & 9 May & 27 Sept. \\
\hline Atlantic & M & 2001 & 9 May & 27 Sept. \\
\hline Inca Purple & M & 2001 & 25 Apr. & 14 Sept. \\
\hline Inca Red & M & 2001 & 25 Apr. & 14 Sept. \\
\hline Kitamurasaki & M & 2001 & 25 Apr. & 14 Sept. \\
\hline Hokkai No. 91 & M & 2001 & 25 Apr. & 14 Sept. \\
\hline Hokkai No. 92 & M & 2001 & 25 Apr. & 14 Sept. \\
\hline
\end{tabular}

* 12 samples described in our previous study. ${ }^{7 * *} \mathrm{M}$, the experimental farm at the National Agricultural Research Center for the Hokkaido Region at Memuro; J, the farm near Jinno Starch Co.

cultivar used for starch production. Irish Cobbler, May Queen, Kita-akari, and Touya are mainly used for direct fresh consumption, and Toyoshiro, Hokkaikogane, Waseshiro, Norin No. 1, and Sayaka are primarily used for food processing. These 16 representative cultivars, including 7 used for starch production and 9 used for purposes other than starch production, were grown under three-tosix different cultivation conditions. Thus, three to six starches from each cultivar were obtained. The mean values of the contents of amylose and phosphorus and mean granule size of starches from these cultivars are listed in Table 2. Among the cultivars studied, the mean amylose content ranged from $17.1 \%$ in Waseshiro to $22.4 \%$ in Norin No. 1. Sabiniano et al ${ }^{\text {() }}$ reported that the blue value at $680 \mathrm{~nm}$, which represents the amylose content, varied in the following order: Benimaru $>$ Toyoshiro $>$ Konafubuki. The present results agree with their findings. No difference in the mean amylose content was found between the cultivars used for starch production (Konafubuki, Benimaru, Eniwa, etc.) (20.2\%) and those not mainly used for starch production (Irish Cobbler, May Queen, Kita-akari, etc.) (19.5\%). The cultivars differed widely in their mean phosphorus content of starches. The highest found was $1012 \mathrm{ppm}$ in Touya, and the lowest was 604 ppm in Benimaru. In previous reports, ${ }^{4,5)}$ Eniwa had a higher phosphorus content than Norin No. 1 and Benimaru. Sabiniano et al. ${ }^{6}$ found that Benimaru contained starch with a lower phosphorus content than Toyoshiro and Konafubuki. Our data are in agreement with these results. 
Manifest differences in the mean values of mean starch granule size were observed among the cultivars studied. Sakurafubuki had the highest mean value of mean granule size $(43.7 \mu \mathrm{m})$ followed by Astarte $(43.6 \mu \mathrm{m})$ and Benimaru $(43.6 \mu \mathrm{m})$, while Waseshiro had the lowest one $(31.8 \mu \mathrm{m})$. Previous publications indicated that Norin No. 1 had a smaller starch granule size than Benimaru and Eniwa $^{4)}$ and that Toyoshiro had a smaller starch granule size than Benimaru and Konafubuki, ${ }^{6}$ which is in agreement with our data. The cultivars used for starch production had a larger mean value for granule size $(40.7 \mu \mathrm{m})$ than those not mainly used for starch production $(34.8$ $\mu \mathrm{m})$. The results are reasonable because larger starch granules are easy to separate from potato tubers.

The mean values of the RVA pasting parameters of the starches from 16 representative potato cultivars are shown in Table 3. Touya exhibited the highest mean peak viscosity (349 RVU) among all the cultivars examined, followed by Hokkaikogane (341 RVU), Eniwa (330 RVU), and Hokkai No. 87 (330 RVU), while Norin No. 1 had the lowest peak viscosity (211 RVU), and Benimaru had the second lowest (231 RVU). In agreement with our data, Yagi et al. ${ }^{3)}$ and Suzuki et al . ${ }^{5)}$ reported that the peak viscosity determined by the Brabender Viscograph and RVA, respectively, was lower in Benimaru and Norin No. 1 than in Eniwa. Additionally, Sabiniano et al. ${ }^{6}$ ) reported that Benimaru contained starch with a lower peak viscosity than Toyoshiro and Konafubuki. The mean breakdown was in the range of 97-229 RVU among all the cultivars examined. The order of breakdown among the cultivars was similar to that of peak viscosity. A relatively narrow range of the mean pasting temperature $\left(66.7-70.3^{\circ} \mathrm{C}\right)$ was

Table 2. Mean values of the content of amylose and phosphorous and mean granule size among 16 representative potato cultivars.

\begin{tabular}{|c|c|c|c|c|}
\hline Cultivar & No. of samples & Amylose content $(\%)$ & Phosphorus content (ppm) & Mean granule size $(\mu \mathrm{m})$ \\
\hline \multicolumn{5}{|c|}{ Cultivars used for starch production } \\
\hline Konafubuki & 6 & $19.9 \pm 0.6$ & $777 \pm 35$ & $38.6 \pm 2.4$ \\
\hline Benimaru & 6 & $22.0 \pm 1.1$ & $604 \pm 53$ & $43.6 \pm 1.2$ \\
\hline Eniwa & 5 & $17.4 \pm 1.9$ & $919 \pm 127$ & $37.9 \pm 2.5$ \\
\hline Sakurafubuki & 3 & $20.8 \pm 1.3$ & $698 \pm 41$ & $43.7 \pm 2.2$ \\
\hline Astarte & 3 & $22.0 \pm 0.8$ & $632 \pm 49$ & $43.6 \pm 3.0$ \\
\hline Early Starch & 4 & $21.7 \pm 1.0$ & $814 \pm 86$ & $38.8 \pm 3.2$ \\
\hline Hokkai No. 87 & 4 & $18.1 \pm 0.3$ & $867 \pm 97$ & $40.4 \pm 3.8$ \\
\hline Total & 31 & $20.2 \pm 2.1$ & $761 \pm 133$ & $40.7 \pm 3.4$ \\
\hline \multicolumn{5}{|c|}{$\begin{array}{l}\text { Cultivars used for direct consumption } \\
\text { and/or food processing }\end{array}$} \\
\hline Irish Cobbler & 5 & $19.4 \pm 1.3$ & $795 \pm 104$ & $31.9 \pm 0.9$ \\
\hline May Queen & 3 & $20.0 \pm 0.6$ & $725 \pm 43$ & $38.4 \pm 2.0$ \\
\hline Kita-akari & 3 & $19.9 \pm 0.9$ & $908 \pm 87$ & $34.8 \pm 2.9$ \\
\hline Touya & 3 & $19.1 \pm 0.9$ & $1012 \pm 164$ & $32.1 \pm 2.6$ \\
\hline Toyoshiro & 5 & $20.9 \pm 1.9$ & $775 \pm 93$ & $32.7 \pm 1.2$ \\
\hline Hokkaikogane & 6 & $18.5 \pm 1.6$ & $970 \pm 134$ & $39.2 \pm 1.7$ \\
\hline Waseshiro & 4 & $17.1 \pm 2.4$ & $923 \pm 126$ & $31.8 \pm 1.8$ \\
\hline Norin No. 1 & 3 & $22.4 \pm 0.5$ & $634 \pm 62$ & $34.5 \pm 0.2$ \\
\hline Sayaka & 3 & $19.5 \pm 1.0$ & $887 \pm 77$ & $37.9 \pm 4.2$ \\
\hline Total & 35 & $19.6 \pm 1.9$ & $853 \pm 147$ & $34.8 \pm 3.5$ \\
\hline
\end{tabular}

Table 3. Mean values of RVA pasting parameters among 16 representative potato cultivars.

\begin{tabular}{|c|c|c|c|c|c|}
\hline Cultivar & No. of samples & $\begin{array}{l}\text { Peak viscosity } \\
\text { (RVU) }\end{array}$ & $\begin{array}{l}\text { Breakdown } \\
\quad(\text { RVU) }\end{array}$ & $\begin{array}{l}\text { Pasting temperature } \\
\left({ }^{\circ} \mathrm{C}\right)\end{array}$ & $\begin{array}{l}\text { Peak viscosity } \\
\text { temperature }\left({ }^{\circ} \mathrm{C}\right)\end{array}$ \\
\hline \multicolumn{6}{|c|}{ Cultivars used for starch production } \\
\hline Konafubuki & 6 & $275 \pm 18$ & $153 \pm 20$ & $68.6 \pm 0.8$ & $83.4 \pm 4.3$ \\
\hline Benimaru & 6 & $231 \pm 19$ & $128 \pm 21$ & $67.9 \pm 0.6$ & $85.0 \pm 5.2$ \\
\hline Eniwa & 5 & $330 \pm 39$ & $224 \pm 36$ & $67.7 \pm 1.0$ & $77.1 \pm 5.6$ \\
\hline Sakurafubuki & 3 & $247 \pm 8$ & $111 \pm 11$ & $70.3 \pm 1.4$ & $91.3 \pm 2.8$ \\
\hline Astarte & 3 & $241 \pm 17$ & $134 \pm 14$ & $68.5 \pm 0.3$ & $83.8 \pm 3.5$ \\
\hline Early Starch & 4 & $320 \pm 12$ & $201 \pm 19$ & $68.1 \pm 1.4$ & $78.5 \pm 4.2$ \\
\hline Hokkai No. 87 & 4 & $330 \pm 28$ & $225 \pm 30$ & $66.7 \pm 1.3$ & $73.0 \pm 1.6$ \\
\hline Total & 31 & $282 \pm 46$ & $169 \pm 49$ & $68.1 \pm 1.3$ & $81.5 \pm 6.5$ \\
\hline \multicolumn{6}{|c|}{$\begin{array}{l}\text { Cultivars used for direct consumption } \\
\text { and/or food processing }\end{array}$} \\
\hline Irish Cobbler & 5 & $260 \pm 15$ & $130 \pm 13$ & $68.8 \pm 0.9$ & $87.4 \pm 2.5$ \\
\hline May Queen & 3 & $277 \pm 12$ & $161 \pm 12$ & $67.7 \pm 0.9$ & $80.7 \pm 2.3$ \\
\hline Kita-akari & 3 & $306 \pm 27$ & $178 \pm 23$ & $68.3 \pm 1.1$ & $78.9 \pm 1.0$ \\
\hline Touya & 3 & $349 \pm 49$ & $229 \pm 37$ & $67.3 \pm 1.2$ & $75.1 \pm 1.5$ \\
\hline Toyoshiro & 5 & $275 \pm 25$ & $160 \pm 21$ & $68.0 \pm 0.9$ & $81.4 \pm 2.8$ \\
\hline Hokkaikogane & 6 & $341 \pm 46$ & $225 \pm 39$ & $67.9 \pm 0.9$ & $77.0 \pm 4.4$ \\
\hline Waseshiro & 4 & $319 \pm 69$ & $201 \pm 59$ & $67.6 \pm 0.4$ & $76.9 \pm 5.0$ \\
\hline Norin No. 1 & 3 & $211 \pm 27$ & $97 \pm 18$ & $68.5 \pm 0.6$ & $91.4 \pm 4.8$ \\
\hline Sayaka & 3 & $306 \pm 34$ & $185 \pm 30$ & $67.9 \pm 0.9$ & $78.1 \pm 2.0$ \\
\hline Total & 35 & $296 \pm 52$ & $176 \pm 50$ & $68.0 \pm 0.9$ & $80.7 \pm 5.8$ \\
\hline
\end{tabular}


observed among all the cultivars studied. In contrast, the mean peak viscosity temperature differed widely among the cultivars. Norin No. 1 exhibited the highest mean peak viscosity temperature $\left(91.4^{\circ} \mathrm{C}\right)$ among all the cultivars examined, followed by Sakurafubuki $\left(91.3^{\circ} \mathrm{C}\right)$ and Irish Cobbler $\left(87.4^{\circ} \mathrm{C}\right)$, while Hokkai No. 87 had the lowest peak viscosity temperature $\left(73.0^{\circ} \mathrm{C}\right)$. The mean values of all four RVA parameters for the cultivars used for starch production were similar to those for cultivars not mainly used for starch production.

Second, we evaluated the ranges of the starch properties using a large number of potatoes, including those from minor cultivars. The mean and range of the contents of amylose and phosphorus, mean granule size, and RVA pasting parameters for composite samples of the 66 potato starches mentioned above and 30 potato starches from minor cultivars are presented in Table 4 . The contents of amylose and phosphorus ranged from 11.4 to $24.2 \%$, and from 510 to $1334 \mathrm{ppm}$, with mean values of $19.3 \%$ and 846 ppm, respectively. Thus, we could not detect starches with a high ${ }^{8)}\left(\right.$ more than $30 \%$ ) or low ${ }^{9)}$ (less than 10\%) amylose content in this study. The range of the phosphorus content was similar to that reported by Veselovsky ${ }^{10)}$ (630-1240 ppm), Wiesenborn et al ${ }^{11)}$ (609-1031 ppm), and Kim et al . ${ }^{12)}(596-1022 \mathrm{ppm})$. In contrast, some differences were found between the present results and those reported by Murakami et al .) (280-1010 ppm), Suzuki et al . ${ }^{5)}$ (367-973 ppm), and Haase and Plate ${ }^{13)}$ (430-1096 $\mathrm{ppm})$. These differences in the findings of the studies cited and ours may be due to the cultivar and/or analytical method used to determine the phosphorus content. The mean granule size varied from 25.5 to $46.8 \mu \mathrm{m}$ with a mean value of $37.5 \mu \mathrm{m}$. Higher values of mean granule size were reported by Wiesenborn et al. ${ }^{11)}$ (38.7-53.8 $\mu \mathrm{m})$, while lower values were reported by Murakami et al. ${ }^{4)}(16.5-27.5 \mu \mathrm{m})$. These results are presumably attributed to the difference in the cultivar and/or the method for measurement of granule size. As for the pasting properties by RVA, there were vast ranges of peak viscosity (185-459 RVU), breakdown (77-324 RVU), and peak viscosity temperature $\left(73.1-95.0^{\circ} \mathrm{C}\right)$, while the range of the pasting temperature was relatively narrow $\left(64.9-71.5^{\circ} \mathrm{C}\right)$.

Large differences in all starch parameters, except the pasting temperature, were considered sufficient to allow a valid analysis of correlation coefficients. Third, the correlation coefficients among all starch parameters, except the pasting temperature, were calculated to study the contribution of componental characteristics and granule size to pasting properties, and the results are summarized in Table 5. The phosphorus content was negatively correlated

Table 4. Mean and range of starch parameters in 96 potato starches.

\begin{tabular}{lcc}
\hline \multicolumn{1}{c}{ Starch properties } & Mean \pm SD & Range \\
\hline Amylose content & $19.3 \pm 2.3$ & $11.4-24.2$ \\
Phoshorus content $(\mathrm{ppm})$ & $846 \pm 167$ & $510-1334$ \\
Mean granule size $(\mu \mathrm{m})$ & $37.3 \pm 4.8$ & $25.5-46.8$ \\
Peak viscosity $(\mathrm{RVU})$ & $302 \pm 56$ & $185-459$ \\
Breakdown $(\mathrm{RVU})$ & $183 \pm 55$ & $77-324$ \\
Pasting temperature $\left({ }^{\circ} \mathrm{C}\right)$ & $68.2 \pm 1.1$ & $64.9-71.5$ \\
Peak viscosity temperature $\left({ }^{\circ} \mathrm{C}\right)$ & $80.4 \pm 6.2$ & $71.3-95.0$ \\
\hline
\end{tabular}

with the amylose content $(p<0.01)$, supporting the fact that starch-bound phosphate is located in amylopectin but not in amylose. It is widely accepted that high amylose is the major factor contributing to low peak viscosity, since the extent of starch swelling is presumed to be interrupted by an increase in the amylose content. ${ }^{14-16)}$ However, Wiesenborn et al ${ }^{11)}$ and Ganga and Corke ${ }^{17)}$ reported, with the use of many potato starches, that the amylose content did not have an effect on the peak viscosity. In other studies, it has been well established that starch-bound phosphate manifestly enhances the peak viscosity in potato. ${ }^{10-12)}$ According to the report of Wiesenborn et al.,11) the peakpaste time, which means peak viscosity temperature, is negatively correlated with the phosphorus content $(p<$ 0.01 ) but is not correlated with the amylose content. Our previous study confirmed that the phosphorus content was highly and positively correlated with the breakdown $(p<$ $0.01)$ and peak viscosity $(p<0.01)$, while the amylose content was not correlated with peak viscosity and was negatively but weakly correlated with breakdown $(p<$ $0.05)$ in 12 potato starches. ${ }^{7)}$ In this study, we attempted to elucidate the relationship between the structural properties, amylose and phosphorus contents, and pasting properties using a total of 96 potato starches. The peak viscosity, breakdown, and peak temperature against the content of amylose and phosphorus are given in Fig. 1. The amylose content was negatively correlated with the peak viscosity $(p<0.01)$ and breakdown $(p<0.01)$ but positively correlated with the peak viscosity temperature $(p<0.01)$. On the other hand, the phosphorus content was positively correlated with the peak viscosity $(p<0.01)$ and breakdown $(p<0.01)$ but negatively correlated with peak viscosity temperature $(p<0.01)$. The correlation coefficients between the phosphorus content and pasting properties were higher than those between the amylose content and pasting properties. Thus, our previous ${ }^{7)}$ and present studies indicated that the phosphorus content had a stronger impact on the pasting properties than the amylose content in potato starch. Similar results have been previously reported in potato starch by Wiesenborn et al ${ }^{11)}$ Analysis of the phosphorus content is assumed to be useful for predicting the pasting properties in potato starch. The mean granule size was not significantly correlated with the peak viscosity, breakdown, or peak viscosity temperature. In agreement with our results, Wiesenborn et al ${ }^{11)}$ found that the mean granule size did not correlate with the peakpaste time, which represents the peak viscosity tempera-

Table 5. Correlation coefficients among starch parameters in 96 potato starches.

\begin{tabular}{lrrrrr}
\hline & 1 & 2 & 3 & 4 & 5 \\
\hline $\begin{array}{l}\text { 1. Amylose } \\
\text { 2. Phosphorus } \\
\text { content }\end{array}$ & $-0.61^{* *}$ & & & & \\
3. Mean granule & $0.23^{*}$ & -0.11 & & & \\
$\quad$ size & & & & & \\
4. Peak viscosity & $-0.58^{* *}$ & $0.87^{* *}$ & 0.06 & & \\
5. Breakdown & $-0.56^{* *}$ & $0.81^{* *}$ & 0.13 & $0.97^{* *}$ & \\
6. Peak viscosity & $0.44^{* *}$ & $-0.61^{* *}$ & -0.06 & $-0.80^{* *}$ & $-0.87^{* *}$ \\
$\quad$ temperature & & & & & \\
\hline
\end{tabular}

${ }^{* *}$ Significant at 0.01 level, ${ }^{*}$ Significant at 0.05 level. 


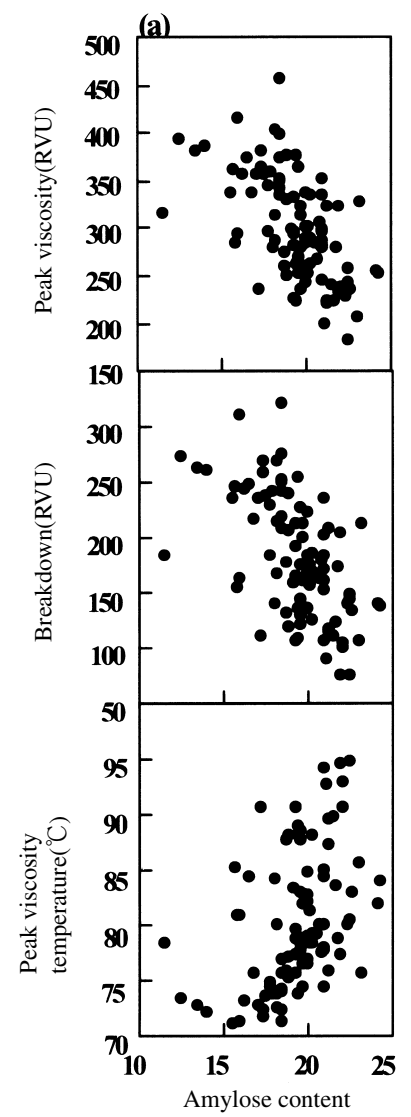

(\%)

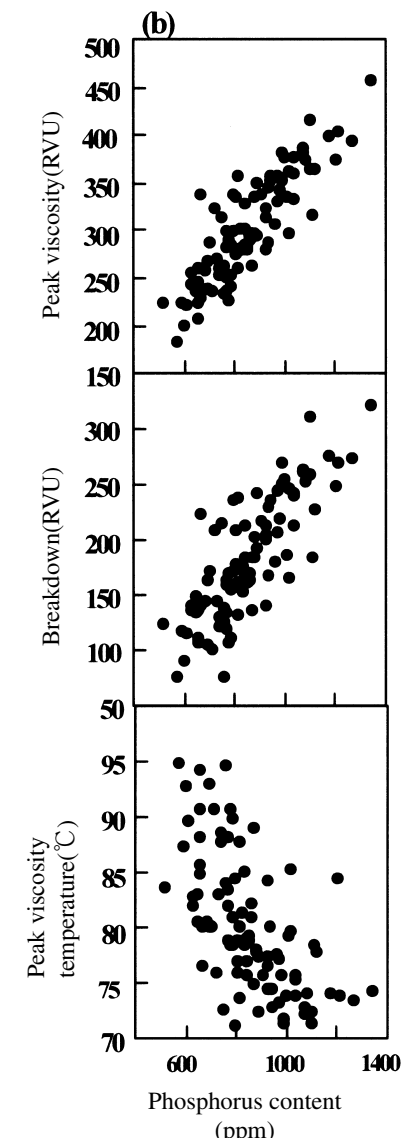

(ppm)

Fig. 1. Relationships between either amylose content (a) or phosphorus content (b), and either peak viscosity, breakdown or peak viscosity temperature.

ture, and peak viscosity.

This study showed manifest differences in starch parameters among the 96 potato starch samples used. The phosphorus content had a stronger effect on the starch pasting properties than the amylose content. Such a relationship between the componential characteristics and pasting properties will help researchers to better understand starch behavior and utilization.

The authors thank Dr. Kanenori Takata, National Agricultural Research Center for the Hokkaido Region (Present affiliation: National Agriculture Research Center for the Western Region), for the use of Sympatec HELOS Particle Size Anaylsis. This work was supported in part by Special Coordination Funds for Promoting Science and Technology (Leading Research Utilizing Potential of Regional Science and Technology) of the Ministry of Education, Culture, Sports, Science and Technology of the Japanese Government and also funded in part by the Research and Development Program for New Bio-industry Initiatives of the Bio-oriented Technology Research Advancement Institution (BRAIN).

\section{REFERENCES}

1 ) M. Mori: Breeding of potato varieties to meet changing demand. Farm. Jpn. 35, 10-15 (2001).

2 ) S. Hizukuri, S. Tabata and Z. Nikuni: Studies on starch phosphate: Part 1. Estimation of glucose 6-phosphate residues in starch and the presence of tuber bound phosphate(s). Starch/ Stärke, 22, 338-343 (1970).

3 ) T. Yagi, T. Shimomura and S. Yoshioka: Ash contents of potato starch prepared from five varieties of potato in Hokkaido. Denpun Kagaku, 19, 122-128 (1972). (in Japanese with English abstract)

4 ) N. Murakami, K. Asama, H. Itoh and T. Itoh: Studies on starch in potato breeding I. Variations in diameter of starch granule and inorganic constituents among various potato varieties, and effects of fertilizer levels on these characteristics. Denpun Kagaku, 25, 178-185 (1978). (in Japanese with English abstract)

5 ) A. Suzuki, K. Shibanuma, Y. Takeda, J. Abe and S. Hizukuri: Structure and pasting properties of potato starches from Jaga Kids Purple '90 and Red '90. J. Appl. Glycosci., 41, 425-432 (1994).

6 ) N.S. Sabiniano, K. Ishibashi and K. Hironaka: Effect of lowtemperature storage on some properties of potato starch. Nippon Shokuhin Kagaku Kogaku Kaishi, 42, 815-819 (1995).

7 ) T. Noda, S. Tsuda, M. Mori, S. Takigawa, C. Matsuura-Endo, K. Saito, W.H.A. Mangalika, A. Hanaoka, Y. Suzuki and H. Yamauchi: The effect of harvest dates on the starch properties in various potato cultivars. Food Chem., 86, 119-125 (2004).

8 ) G.P. Schwall, R. Safford, R.J. Westcott, R. Jeffcoat, A. Tayal, Y.-C. Shi, M.J. Gidley and S.A. Jobling: Production of veryhigh-amylose potato starch by inhibition of SBE A and B. $\mathrm{Na}$ ture Biotechnol., 18, 551-554 (2000).

9 ) J.H.M. Hovenkamp-Hermelink, E. Jacobsen, A.S. Ponstein, R. G.F. Visser, G.H. Vos-Scheperkeuter, E.W. Bijolt, J.N. de Vries, B Witholt and W.J. Feenstra: Isolation of an amylosefree starch mutant of the potato (Solanum tuberosum L.). Theor. Appl. Genet., 75, 217-221 (1987).

10) I.A. Veselovsky: Biochemical and anatomical properties of starch of different varieties of potatoes and their importance for industrial purposes. Am. Potato J., 17, 330-339 (1940).

11) D.P. Wiesenborn, P.H. Orr, H.H. Casper and B.K. Tacke: Relationship between potato starch paste behavior and selected physical/chemical properties. J. Food Sci., 58, 644-648 (1994).

12) Y.S. Kim, D.P. Wiesenborn, P.H. Orr and L.A. Grant: Screening potato starch for novel properties using differential calorimetry. J. Food Sci., 60, 1060-1065 (1995).

13) N.U. Haase and J. Plate: Properties of potato starch in relation to varieties and environmental factors. Starch/Stärke, 48, 167-171 (1996).

14) L.S. Collado, R.C. Mabesa and H. Corke: Genetic variation in the physical properties of sweet potato starch. J. Agric. Food Chem., 47, 4195-4201 (1999).

15) C.K. Black, J.F. Panozzo, C.L. Wright and P.C. Lim: Survey of white salted noodle quality characteristics in wheat landraces. Cereal Chem., 77, 468-472 (2000).

16) T. Beta and H. Corke: Noodle quality as related to sorghum starch properties. Cereal Chem., 78, 417-420 (2001).

17) Z.N. Ganga and H. Corke: Physical properties of starch of Asian-adapted potato varieties. J. Sci. Food Agric., 79, 16421646 (1999). 


\section{北海道産馬鈴薯品種の澱粉特性}

野田高弘 ${ }^{1}$, 津田昌吾 ${ }^{1}$ ，森 元幸 ${ }^{1}$ ，㴰川重信 ${ }^{1}$,

遠藤千絵1, 橋本直人 ${ }^{2}$, 山内宏昭 ${ }^{1}$

1 農業・生物系特定産業技術研究機構

北海道農業研究センター畑作研究部

(082-0071 北海道河西郡芽室町新生)

2 北海道大学大学院農学研究科

(060-8589 札幌市北区北 9 条西 9丁目)

北海道で栽培した馬鈴薯を用い, 塊茎中の澱粉特性に ついて調べた．本研究で分析した項目は，アミロース含 量, リン含量, 粒度分布, ラピッドビスコアナライザー による粘度特性であった．使用した 96 馬鈴著澱粉試料間 での澱粉特性值において，大きな差異が見いだされた。

澱粉のリン含量が高いものは, ピーク粘度, ブレークダ ウンが高く，ピーク粘度時温度が低いことが確認された。 アミロース含量も粘度特性に影響を及ぼしたが, リン含 量と粘度特性值との間の相関係数は, アミロース含量と 粘度特性值との間の相関係数よりも高かった。 